George Macartney, then Consul-General at Kashgar, for transmission to Calcutta at the instance of Hoernle, who greatly encouraged Stein in his design of investigating their source. It was therefore from the first an archæological rather than a geographical exploration on which Stein started. His first expedition to Central Asia was delayed until 1900, when he set out via Gilgit and Kashgar for a year in the region of the Taklamakan Desert.

It is impossible even to sketch here the course or routes of Stein's three Central Asian journeys. They have been fully reported from several points of view by Stein himself, in narrative volumes, in full-length reports and also in two excellent and compendious sketches, a paper given before the Royal Geographical Society with the title "Innermost Asia: its Geography as a Factor in History", and published in the Geographical Journal of May and June 1925, and the section on his own archrological work in Central Asia which he contributed to an account of the work of the Archæological Survey of India published by the India Society in 1939 under the title "Revealing India's Past". Here we can only attempt a general estimate of his method and its fruits. His research was historical and directed especially to the solution of one historical problem-the elucidation of the relations between China and the West, the capacity of the trade routes, the nature of the cultural influences passing along them, the periods which saw these routes most used and the causes which led to the abandonment of them and of the settlements along their course. A striking fact is that whereas he started out with the idea above all of tracing the eastward expansion of the cultural influences of the Hellenistic West, and of India, he came more and more to be impressed by the purpose, organizing power and tenacity of the Chinese who opened these routes and so long maintained them. Hellenistic influence was found to end in the early years of the fourth century A.D., but Indian influence was long continued by the passage of Chinese pilgrims to the Buddhist shrines in India. For the early period his most important discovery was of the elaborate organization of a Chinese limes in the Han period, protecting the route through the Tunhuang Oasis and beyond from the incursions of the nomads of the steppe to the north; and of the route, across the bed of the dried-up inland Sea of Lop, connecting this region with Kucha without passing through the relatively exposed Turfan region.

For the history of art Stein's most important finds were the textiles of the Astana cemetery and the cache of paintings and manuscripts in the walled-up chamber at the Caves of the Thousand Buddhas, near Tun-huang. These with the wall paintings, transported from the sites of Bazaklik, Murtuk, Miran and elsewhere to the new Central Asian Antiquities Museum at New Delhi, have added so much to the material for the study of Buddhist painting in China in the T'ang period as to revolutionize it. Unfortunately, the wall paintings, though listed by Dr. Andrews in his Catalogue of 1933, have not yet been published, and are therefore not yet fully available to students. The Tun-huang paintings, on the other hand, have been fully catalogued by Mr. Arthur Waley, and the whole series was mounted at the British Museum and a great part exhibited there in 1914 on the occasion of the opening of the King Edward Building. The collection was afterwards divided between the British Museum and the Government of India for the Museum at New Delhi, but in
1921 the two Museums brought out jointly a portfolio of reproductions in colour of selected examples from both collections, with an introduction by Laurence Binyon and descriptions by Stein himself. Their importance has therefore been fully realized, though much work remains to be done on them from the stylistic and iconographical sides.

Stein went no more to Central Asia, except for a brief and abortive journey. But, though prevented from following up one line of research, he started on the archæological survey of another great region. $\mathrm{He}$ had already traversed Sistan on his return from the third Central Asian expedition, and he now began a series of journeys which eventually' covered the whole of that great bridge between the civilizations of East and West which leads from Mesopotamia, over the Iranian plateau, through Afghanistan, and so down into the Indus Valley; or across the Oxus into Turkestan. During all this period of more than twenty years he had two bases, his camp in the Kashmir highlands, and Corpus Christi College at Oxford, where the late president, Dr. P. S. Allen, the Erasmus scholar, always welcomed his friend on his visits to England. Of these journeys, the most important were the tours of the chalcolithic sites of Baluchistan in 1926-27 and 1927-28, and, since 1930, in south-western Persia. His accounts of the first were published by the Archæological Survey of India in its series of Memoirs ; the later journies undertaken after his retirement from its service were chronicled in two large volumes. He also made expeditions to the Upper Indus region and followed the Roman frontier limes in Mesopotamia.

In all this wide area, Stein followed the course of ancient trade routes with his trained eye and indefatigable zeal. His pertinacity and complete absence of fear carried him over the wildest and most forbidding country. Indeed he was most truly himself when, with his surveying staff and train of porters alone, he viewed from some almost inaccessible spot ancient tracks and, as it were, a whole panorama of past history. Where written texts could illumine the records which he found on the ground, all the evidence which he found fell into a pattern. But in a region of such a long and complex history as he was now exploring, it was not to be expected that Stein should have been able to reach conclusions as definitive as in Central Asia. His explorations have mapped the sites which need to be studied : they call for the methods of the trained excavator and much comparative study before they can yield all their evidence.

Aurel Stein loved solitude. He was happy in a study, but happier in the wide open spaces. When he appeared in the lecture room, as he did in the United States at the Fogg Museum and elsewhere, and in London especially in the Royal Geographical Society's rooms, it was the nervous force of his small compact body and his piercing eye which impressed one with his indomitable spirit even more than the substance of what was said. At over eighty he was hoping to embark on a fresh field of exploration from Kabul, where death claimed him. It was his wish that his body should rest amid the beautiful scenery of Kashmir.

Bastl Gray.

\section{Dr. M. Radford}

The passing of Dr. Maitland Radford, medical officer of health of St. Pancras, at the age of fifty-nine, is of more than local or professional significance. He was a rationalist, reared in a progressive if not 
revolutionary atmosphere, with Shaw, Wells, William Morris and Bradlaugh as friends of his family. He was a nephew of Graham Wallas, whose influence he always gratefully acknowledged. Educated at Abbotsholme and University College Hospital, his career in public health was that of a successful and efficient sanitarian. But, as a close colleague of his has written, "he was not a man to allow the local trees to obscure his vision of the public bealth wood, or as he might have said, the public health jungle".

Widely and deeply read in literature, philosophy and economics, it was perhaps in health education in its widest sense that he found great satisfaction. The Central Council for Health Education, of which he was vice-chairman, owes much to him. But it was not the leaflet or the poster or the film which interested him most. It was rather the plan, the purpose of it all, the thought of the human personality rather than its physical frame.

He was a man of principles and ideas, preferring the long to the short view. Modest and urbane in manner, he was frank in the confession of his doubts, and both adamant and passionate in defence of principle. He was one of the few men of whom it can truthfully be said that nothing would induce him to say and do anything which he did-not believe to be right. His defence of the secular approach to moral problems at a recent conference on venereal disease, at which the Archbishop of Canterbury was the principal speaker, will long be remembered by those who heard it.

In conference or conversation-he preferred conversation-the ideas simply tumbled out, or to be more accurate, shot out. Some he pursued himself, others he left his colleagues to pursue. Strange though the country through which they led the pursuer, they were worth pursuing. $\mathrm{He}$ prodded the conventional-but oh, so gently. He flicked the obstinate with a wit as innocent as it was penetrating. $\mathrm{He}$ 'rollicked' the reactionary with a mirth that was infectious. He was, above all, a thinker; and with the world as it is, that marked him out and adds to our sense of loss.

C. HILL.

WE regret to announce the following deaths :

Dr. Carl Bonhoeffer, successively professor of neurology at Königsberg, Breslau and Berlin and one of the editors of the Monatschrift für Psychiatrie, Allgemeine Zeitschrift für Psychiatrie and Zentralblatt für Neurologie und Psychiatrie, aged seventy-five.

Mr. Christopher Dalley, president of the Institute of Petroleum, an authority on petroleum engineering, on January 27, aged sixty.

Dr. A. Stansfield, emeritus professor of metallurgy, MeGill University, on February 5, aged seventy-two.

\section{NEWS and VIEWS}

\section{Scientific Terminology}

The enormous waste of human time and energy, nay also of human life, that has been caused by the use of wrong or vague words, and the misuse of good words, is well known to students of human thought through the ages. Many words have changed their meanings in the course of time, and new words have been adopted with ambiguous or multiple connotations. Though one would hesitate to suggest that the legal profession has been the chief perpetrator of such intellectual delinquencies, and of their sequelce-for the theologians and philosophers must have run them very close-there is no doubt that the loose drafting of governmental Bills and Regulations, even up to the present day, has caused great confusion and, incidentally, served to redistribute wealth in a unilateral direction. As Mephistopheles remarked, "Mit Worten lässt sich trefflich streiten, Mit Worten ein System bereiten, Von einem Wort kein Iota rauben".

To-day most new words originate in the sciences or their applications, and many of them have been condemned or eriticized owing to their lack of precision, their hybrid etymology, their ugliness or unwieldiness, or because they signify something different from identical or similar words used in common parlance. It has often been deplored that in Britain we have no institution or high authority to adjudicate on new words, like the French Academy does for France, albeit often with much delay; but there seems to be no reason why the scientific world should not take the bit between its teeth and appoint its own authority for rectifying bad words, including spelling, devising new words or deciding between rival suggestions. An 'omnibus' body, like the Royal Society, is clearly indicated to assume such a task. Through ad hoc subcommittees for groups of sciences, assisted by a few language experts, it could provide authoritative guidance, if not compulsory ruling, for scientific research workers, who are seldom as good at word-building as they are at 'things'. The main committee might also attack the problem of an international auxiliary language for use in science and technology.

\section{Photographic Terminology}

The above reflexions arise from a perusal of a letter addressed to the scientific Press by the editor of Photographic Abstracts, entitled "Microphotography and Photomicrography, and other Terminological Inexactitudes". Although these two terms, signifying the production of very small photographs and the photographic reproduction of very small objects, respectively, are clear enough to experts, they are confusing to other people, and one can support the author's plea for the standardization of these and similar terms. 'Micro-' and 'macro-', he suggests, should be used in photography with a definite quantitative meaning only, and one might go farther and suggest that when these prefixes are used for scientific words, they should bear a precise quantitative meaning, as in microgram and microhm, leaving their vaguer signification to popular words like microcosm, macrocosm and perhaps 'microcookery' (the cooking of war-time rations). The word 'radiogram' is one that needs immediate attention, as it has three distinct meanings : (1) a combination of radio-receiver and gramophone, (2) a telegram transmitted by radio, and (3) an X-ray photograph (also called a radiograph or a skiagraph). Probably (3) would be best for scientific use. The word 'radio' itself might be banned from scientific writing, for, at least etymologieally, it might refer to any kind of radiation. But such difficulties as these are not to be solved offhand; they would best be considered by an authoritative body, as suggested above. 